\title{
Morphological, molecular and pathological appraisal of Hymenolepis nana (Hymenolepididae) infecting laboratory mice Mus musculus
}

\section{Ebtsam Al-Olayan}

King Saud University College of Science

Rewaida Abdel-Gaber ( $\nabla$ rewaida@sci.cu.edu.eg )

King Saud University https://orcid.org/0000-0001-9263-6871

Abeer Aloufi

King Saud University College of Science

\section{Zainab Alanazi}

King Saud University College of Science

Research article

Keywords: Laboratory animals; Rodents; Hymenolepis species; Morphological characterisation; Molecular analyses

Posted Date: October 1st, 2019

DOl: https://doi.org/10.21203/rs.2.14737/v1

License: (c) (i) This work is licensed under a Creative Commons Attribution 4.0 International License. Read Full License

Version of Record: A version of this preprint was published at Microscopy and Microanalysis on March 5th, 2020. See the published version at https://doi.org/10.1017/S1431927620000161. 


\section{Abstract}

Background: Hymenolepis nana, commonly found parasite in mice colonies maintained under conventional conditions, has zoonotic potential and is characterised by autoinfection and direct life cycle. Results: This study intended to determine parasitic infection rate in laboratory mice. Of the 50 mice, $40.0 \%$ were found to be infected with hymenolepidid cestode. Infection rate was higher in males (52.0\%) than in females (28.0\%). Light and scanning electron microscopic studies of cestode parasite revealed that the worms were medium-sized; had globular scolex with four suckers, a retractable rostellum equipped with 20-30 hooks, and a short unsegmented neck; remaining strobila consisted of immature, mature, and gravid proglottids; irregularly alternating genital pores; lobulated ovary; post-ovarian vitelline gland; and uterus containing $₫ 200$ small eggs in gravid proglottids. Molecular characterisation based on mitochondrial COX1 gene sequence analysis used to confirm taxonomy of the parasite. The parasite

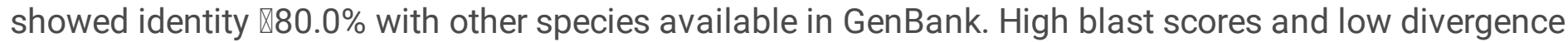
were noted between isolated parasite and previously described $\mathrm{H}$. nana (gb| AP017666.1). Phylogenetic analysis using COX1 sequence place this hymenolepidid species within Cyclophyllidea. Conclusions: The present species was found to be deeply embedded in the genus Hymenolepis with close relationships to other $\mathrm{H}$. nana as a putative sister taxon.

\section{Text}

The authors have retracted the text of this preprint. 